\title{
Consumer innovativeness, product innovation and smart toys
}

\author{
Fangyu Zhang ${ }^{1}$, Siwei Sun ${ }^{1}$, Chenlin Liu $^{2}$, Victor Chang ${ }^{3 *}$
}

1. Business School, University of Auckland, Auckland, New Zealand

2. School of Economics and Management, Tsinghua University, Beijing, China

3. School of Computing, Engineering and Digital Technologies, Teesside University, Middlesbrough, UK

Email: victorchang.research@gmail.com

\begin{abstract}
Smart toys, a new type of toy, becomes prevalent in the global market because of its fantastic user experience from interacting with various smart toys. Although past literature has concerned the smart toy field, not enough research focus on consumer behavior in the Chinese smart toy market that is a vast and promising market for smart toy producers. Besides, although past literature has verified the effect of product innovativeness, consumer innovativeness, and perceived value on consumers' purchase and adoption intention, the relationships among them still need more study. This research explores the mechanism of how consumer innovativeness leads to consumers' willingness to pay via perceived product innovation and perceived value. Data analys is based on surveys of 399 Chinese people reveals that perceived product innovation and consumer innovativeness contribute to the willingness to pay. Subsequently, perceived social value, one of the dimensions of perceived value, mediates the path between perceived product innovation, and willingness to pay. Next, as the level of consumer innovativeness increases, the effect of perceived product innovation on social value becomes strong. Furthermore, perceived product innovativeness and perceived social value mediate the path between consumer innovativeness and consumers' willingness to pay. This study provides suggestions for researchers and practitioners.
\end{abstract}

Keywords: smart toys, perceived product innovativeness, consumer innovativeness, perceived value, willingness to pay. 


\section{Introduction}

The extensive adoption of the internet of things (IoT) and digitalization have led manufacturers into the Industry 4.0 age, a smarter and faster production age (William, 2014). Smart toys are one type of smart products that incorporate smart technologies into a traditional product to achieve a fantastic playing environment through multimedia use and interactive usability (Kara et al, 2013). As an emerging product category in the toy industry, smart toys have quickly attracted consumer attention. According to the NPD Group (2018), the fastest-growing category in the toy industry in the first half of 2018 was youth electronics, which would continue increasing in 2019 due to the popularity of robotic/interactive playmates. The same report also predicted that hightech products in the toy industry would be the mainstream in the future.

At present, most of the existing research study smart toys focusing on the technology application (e.g., Yang, et al., 2018) and educational experience (e.g., Ekin, et al., 2018). Though a better understanding of consumers' attitudes could provide valuable suggestions to the smart toys industry for future development and enrich the literature on consumers' responses to the innovative products, limited researchers study the consumers' responses to the smart toys. Many researchers studied the consumer adoption behavior on new products, and they proposed several traditional research models, for example, Theory of Reasoned Action (TRA) (Fishbein and Ajzen, 1975), Theory of Planned Behavior (TPB) (Ajzen, 1991), Technology Adoption Model (TAM) (Davis, 1989), Enhanced Technology Acceptance Model (TAM2) (Venkatesh and Davis, 2000), Unified Theory of Acceptance and Use of Technology (UTAUT) (Venkatesh et al, 2003), and Innovation Diffusion Theory (Rogers, 1995). Such research models identify the dominant factors influencing consumers to accept smart toys.

However, two problems remain for solving in studying consumers' responses to the new products. First, the traditional models pay attention to the influence of new products' advanced attributes on consumers' acceptance but ignore the influence of the 
innovation itself on consumers' intention. Roehrich (2004) proposes that people tend to seek novelty for stimulation need, independence toward others' communicated experience, and uniqueness. Accordingly, product innovation may be a significant trigger of consumers' buying intention. Second, only studying adoption behavior on new products is not enough for the real world (i.e.market of new products). Even though consumers accept one new product, they may not pay for it when facing many choices in real life. For example, in the real market, the price of smart toys is usually higher than that of traditional toys in the same category. If consumers prefer to choose smart toys, in general, they will pay a relatively high price. Conversely, if consumers are not willing to pay for the extra money for the new attributes, they may choose traditional products even though they are interested in the new products. In this case, the question that should be paid attention to is not only whether consumers accept the new products but also whether they are willing to pay the additional money for the novelty. Based on these two questions neglected, this paper proposes two research questions: (1) Does consumer innovativeness and product innovation stimulate consumers' paying behavior regarding smart toys? (2) How does product innovation influence consumers' paying behavior?

This research contributes to both literature and practice. As product innovation mainly emerges in organizational studies, our research opens a new insight into studying product innovation from the consumers' perspective. The findings indicate that consumers' perceived product innovation can be regarded as a significant factor influencing consumers' buying behavior, extending the previous research on studying the influential factors of consumers' buying behavior. Furthermore, this research encourages consumer researchers to pay attention to not only adoption behavior but also consumers' paying behavior. The finding that supports the positive effect of consumer innovativeness on consumers' paying behavior enriches the literature on the consequences of consumer innovativeness. In practice, this research helps the sellers of smart toys to acknowledge the importance of emphasizing the unique and novel attributes of products in stimulating consumers' perceived product innovativeness. Also, 
the market targeting group can be more specific into people who have high innovativeness traits and seek after high technologies, because those consumers are easy to generate a favorable impression and positive evaluation on the new products. Moreover, the introduction of products and advertising could be more personalized and social network orientated.

This study introduces the background to the research and the constructs in Part 2. Based on the theoretical background, the paper then proposes the hypotheses and the research model in Part 3. Next, the research methods are presented in Part 4, including the research context, sampling and data collection, measurements, and analys is approach. The following part 5 demonstrates the results of the reliability and validity analysis and hypotheses testing. Next, the contributions to theory and practice and the limitations are discussed in Part 6. Finally, Part 7 concludes the entire study.

\section{Theoretical background}

\subsection{Smart toys}

Smart toy is broadly defined as "a device consisting of a physical toy component that connects to one or more toy computing services to facilitate gameplay in the Cloud through networking and sensory technologies to enhance the functionality of a traditional toy" (Hung et al.,p.128, 2017). Compared with traditional toys, smart toys integrate with sophisticated sensors, actuators, chips, and wireless communication equipment that support the use and interaction of multimedia to cultivate a fantastic playing environment with various tasks and joyful experience for users (Kara et al., 2013; Kara et al., 2014). What distinguishes smart toys from electronic games is the existence in the form of a physical entity, and they can link the virtual world and reality to create multidimensional play environments (Ekin et al., 2018; Cagiltay et al., 2014).

Cagiltay et al. (2014) categorize smart toys into several types by different standards. By the criteria of task pattern, smart toys can be grouped as behavioral-task or cognitive-task toys and non-behavioral task toys. By the criteria of interaction pattern, smart toys can be grouped as interact-with-computers toys or self-contained toys. 
Behavioral-task toys require users to complete interactions with toys by conducting a series of behaviors. A typical example of this kind of toy is Furby, an electronic robotic toy (Hasbro, 2005). Furby can respond to users through twinkling eyes or changing the color of its eyes as its tail is pulled out or tickled. Besides, Furby can speak Furbish, a unique language, and it can learn language by itself (Hasbro, 2012). Furthermore, new Furbys will gradually "grow" from infants whose "brains" are like blank pieces of paper to "mature ones" who have different personalities resulting from the different ways of interaction. Different from behavioral-task smart toys, cognitive-task smart toys can help users learn. An example is Go!GO! Smart Animals, a set of animal-shaped toys that can talk and sing for infants (VTech, 2014). As these animals are put in seven fixed places, the toys can respond to users with appropriate phrases and music, reporting their names, their animal category, the starting letter of their name, and their status.

With the improvement of the design and the technology, several toy manufacture rs have integrated the cognitive tasks and behavioral tasks into one product. The most common form in the market is unassembled robots. This type of product first requires users to build and then program the control of the robot. For example, LEGO released a toy named Boost Creative Toolbox, which won the Tech Toy of the year in 2018 (Tran, 2018). Users can download the apps and follow the step-by-step instructions to build a robot with 840 pieces, sophisticated sensors, and motors (Mangis, 2017). After assembling, users can interact with the robot through a simple computer program taught by the tutorials on the apps. The process of assembling and programming provides users with lots of fun and knowledge of skills, enhancing users' cognitive capabilities.

Another categorization of smart toys proposed by Cagittay et al. (2014) is from an interaction perspective, including interact-with-computer toys and self-contained toys. They asserted that the major difference is that interact-with-computer toys regard the physical entity as an auxiliary; in contrast, self-contained interaction toys provide users with settings, spaces, or environments without requiring the support of external computers.

However, with the prevalence of applications (apps), more and more toy 
manufacturers are incorporating app technology into their products to achieve a convenient and fantastic playing environment. For instance, the manufacturers designed an application for users of Furby, providing a virtual world to help users complete tasks such as feeding, cleaning, and healing. Unlike the interact-withcomputer toys that cannot respond to users if the app is unavailable, self-contained smart toys can provide more functions and help users complete further tasks with the assistance of applications and interact with the users without applications.

\subsection{Perceived product innovativeness}

The common agreement in the literature on innovation is that product innovation plays a vital role in a company's further development. Based on the degree of product innovation, which means the extent of changes in the production and the rate of new product introductions (Calantone et al., 1994; Yalcinkaya et al., 2007), Kleinschmidt and Cooper (1991) divided product innovativeness into three degrees, including high, moderate and low. Highly innovative products can be divided into new-to-the-world products and new product lines. Moderately innovative products refer to new items in existing product lines and also new product lines for the firms rather than the whole market. Finally, low innovative products are improved products. Different from Kleinschmidt and Cooper (1991), many researchers only split product innovation into two classifications, incremental and radical (e.g., Chandy and Tellis, 1998; Lee et al., 2017; Rubera and Kirca, 2012). Radical product innovation uses substantially different core technology, and incremental product innovation involves minor improvements to satisfy existing customer demand. However, different types of product innovation emerge, ranging from incremental to radical. Kahn (2018) lists seven types that are generally recognized, including new uses, line extensions, product improvements, new markets, cost reduction, new category and new-to-the-world.

Since many researchers who devote to studying the path from product innovation to organizational performance regard product innovation as an integral whole rather than something to be classified, they figure out debatable conclusions on the effect of product innovation as they pay attention to different types of product innovation in their 
surveys. For example, Aksoy (2017), Kuncoro and Suriani (2018), and Muigai and Gitau (2018) used 5-points scales in questionnaires and found that product innovation positively influences the market performance, financial performance, and sustainable competitive advantages. However, Dhanora et al. (2018) found that product innovation has an inverted U-shaped relationship with market power by studying panel data. In contrast, Yalcinkaya et al. (2007)'s findings failed to support the relationship between product innovation and market performance. Therefore, researchers may narrow the product innovation into one type in the study.

Given that consumers' judgments of product innovation merely depend on the product attributes (McNally et al., 2010; Fu and Elliott, 2013), the product innovation in this research mainly concerns innovative changes to products, such as new functions and new designs. Therefore, the single judgment standard by consumers may eliminate the influence of the variety of product innovation classifications. This research adopts the term "perceived product innovativeness," which is defined as the degree to which a product viewed by consumers possesses new and unique attributes as compared with other homogenous products, to describe consumers' perception of the innovation of the smart toy. In particular, the researcher adopts the term "innovativeness" instead of "innovation." Innovation in the Collins dictionary is defined as a new thing of doing something or the introduction of new ideas, methods, or things, and innovativeness is defined as the quality of being innovative. Since the perceptions of the degree of innovativeness of a product are different individual by individual, the research deems that "perceived product innovativeness" is more suitable in this study.

\subsection{Consumer innovativeness}

There is no doubt that new product responses are related to consumer innovativeness, which means exploring individual innovativeness is of significance. The first study that relates individual innovativeness to personality traits was by Midgley and Dowling in 1978. They defined the individual innovativeness as the extent to which an individual can accept new knowledge and make innovative decisions without the influence of others, and highlighted its independence against the 
communicated experience, situational effects, and product category. In the same article, Midgley and Dowling (1978) put forward two measurable categories of individual innovativeness. The first one is innate innovativeness that is related to a personality trait, and the second one is actualized innovativeness that is involved in innovative behavior. Innate innovativeness is defined as a generalized unobservable personal inclination regarding innovation in the cross-product context (Im et al,, 2003). Subsequent researchers also used synonyms to label this construct, such as global innovativeness, open-processing innovativeness, and dispositional innovativeness (Bartels and Reinders, 2011). Actualized innovativeness is defined as how fast an individual accepts innovative things. In the market context, actualized innovativeness is represented by the purchase intentions, attitudes towards a new product, the relative time of the adoption of new products and the number of new products owned (Lassar et al., 2005).

However, as innate innovativeness represents the global traits with the highest level of abstraction, Goldsmith and Hofacker (1991) indicated that when studying a specific domain or a specific product category, innate innovativeness would be of little value. In this case, to supply the influence of product category, the term "domain-specific innovativeness" was proposed to explain the actual human behaviors targeted at a specific domain (Midgley and Dowling, 1993). A hierarchy model proposed by Hirunyawipada and Paswan (2006) indicated that the level of abstraction of definitions of innate innovativeness and actualized innovativeness represent two extreme values. Compared with them, the abstraction degree of domain-specific innovativeness is somewhere in between them. Furthermore, Hoffmann and Soyez (2010) gave a detailed explanation of the hierarchy of consumer innovativeness based on the level of abstraction. Their study suggested that innate innovativeness is the construct whose extent of abstraction of definition reaches the highest level, whereas the extent of abstraction of the definition of actualized innovativeness remains the lowest level. However, the domain-specific innovativeness that is defined in a specific domain of interest is more specific than innate innovativeness. Thus, domain-specific 
innovativeness is more suitable than innate innovativeness to predict consumers' buying behavior in terms of the given product category. Therefore, "consumer innovativeness" in this research represents individual innovativeness traits in the domain of smart technologies.

\subsection{Perceived value}

Consumer perceived value has emerged since the 1990s to predict consumers' consumption behavior. The first study to propose this concept is by Zeithaml (1988) through an exploratory survey based on four perspectives, including low price, the consumer wants in a product, quality for the price the consumer pays and gets in return. Accordingly, Zeithaml (1988) defined perceived value as consumers' assessment toward the usage of a good according to how they feel about what they receive and what they are given.

However, as customer perceived value may vary in different contexts, subsequent researchers disagreed with Zeithaml's (1988) definition and provided different understandings of customer perceived value (Chang and Dibb, 2012). Summarized by Sánchez-Fernández and Iniesta-Bonilla (2007), research on consumer value can be divided into two categories: Unidimensional and multidimensional. The unidimensional research regards customer perceived value as a single overall concept based on the "giving vs. getting" trade-off theory (Sánchez-Fernández and IniestaBonilla, 2007; Lin et al., 2005). Given a single item cannot explain the nature of perceived value, several researchers support the development of a multidimensional construct (Lin et al, 2005). A traditional example is the consumption value proposed by Sheth et al. (1991), which divided consumer value into five dimensions, including social value, emotional value, functional value, conditional value, and epistemic value. However, Sweeney and Souter (2001) indicated that the research of Sheth et al. (1991) was conducted under a specific context related to cigarette buying behavior, which may not fit into explaining the general situation. In this case, Sweeney and Souter (2001) developed a four-dimension scale, including functional values for performance and money, social value, and emotional value, which has contributed to the product 
research.

As the multidimensional perceived value considers the different nature of consumers' buying, researchers use different classification methods to target their research domain. For example, Petrick (2002) asserted that consumer value had five dimensions (i.e.quality, emotional response, monetary price, behavioral price, and reputation ). While Mathwick et al., (2001) believed that consumers' experience value could be measured by aesthetic, playfulness, customer return, and service excellence on investment; and brand value could be measured by expressive/social value, emotional value, economic value, and utilitarian value. As this research is concerned with products, the researcher adopts the classifications given by Sweeney and Souter (2001), dividing perceived value into functional values for performance and money, social value, and emotional value.

\subsection{Willingness to pay}

As Schindler (2012) stated, customer-based pricing strategies can be regarded as a good strategy when a company is at the starting stage in setting an initial price. Accordingly, the concept of willingness to pay helps organizations understand what consumers think about the products. However, the concept of willingness to pay varies based on different researchers (Jedidi and Jagpal, 2009). Wang et al. (2007) divided the concept into three categories based on the purchase probability. The first one is floor reservation price and it represents the highest price that a consumer will pay for a product (e.g., 100\% purchase probability). The second one is indifference reservation price and it refers to the price that does not determine consumers' buying behavior (e.g., $50 \%$ purchase probability). The third one is ceiling reservation price, suggesting the minimum price determines a consumer's willingness to or not to pay for a product (e.g., $0 \%$ purchase probability). Given that this research pays attention to consumers' responses to innovative products, this research defines the willingness to pay from the marketing perspective as the amount of money that consumers are willing to pay for a given product. 
At present, willingness to pay is mainly studied in terms of environmental consumption behavior and safe food buying behavior to explore the factors that motivate people to consume environmentally consciously and safely (Krystallis and Chryssochoidis, 2005). Related literature on environmental behavior shows that people's attitudes, beliefs, concerns, knowledge, and personal characteristics have a significant effect on willingness to pay (e.g., Kazeminia et al., 2016; Hultman et al., 2015; Kang et al., 2012; Wei et al., 2018; Xie and Zhao, 2018; Hidrue et al., 2011; Shin et al, 2017; Zhang et al., 2018). However, Krystallis and Chryssohoidis (2005) pointed out that willingness to pay is driven by different factors in different domains, even in different product categories. Accordingly, the results of previous research might not explain consumers' willingness to pay in the smart toy domains. Thus, the current research regards consumers' willingness to pay as a dependent variable to predict consumers' actual behaviors in practice in the smart toy domain.

\section{Hypotheses and research model}

\subsection{Perceived product innovativeness and consumers' willingness to pay}

Related literature has found that product innovation has an essential influence on organizations' market performance (Aksoy, 2017), market driving (Kuncoro and Suriani, 2018), and market power (Dhanora et al., 2018). Accordingly, these findings potentially indicate that product innovation influences consumers' consumption behavior. Product innovation includes different orientations, such as cost reduction, production line innovation, adding new attributes or functions to a product, and improving the existing attributes and functions. In this case, the changes to product attributes and functions, as two of the orientations of product innovation, may influence consumers' consumption behavior. In other words, innovative products may be more attractive to consumers. When generating a high innovativeness attitude towards a product, consumers may be more willing to buy, even willing to pay a higher price. Thus, Hypothesis 1 is formulated:

H1: Perceived product innovativeness positively stimulates consumers' willingness to 
pay.

\subsection{Perceived product innovativeness, perceived value, and consumers' willingness to pay}

Consumer value is regarded as a guide for companies to price their products (e.g., Smith, 2012; Schindler, 2012; Monroe, 2002; Meehan, 2011). Zeithaml (1988) defined consumers' perceived value as consumers' assessment toward the usage of a good according to how they feel about what they receive and what they give. He also proposed that perceived value has a significant effect on consumers' decision making. Therefore, regarding the indirect relationship between perceived product innovativeness and willingness to pay, we incorporate perceived value into the research model. In terms of studying perceived value towards products, perceived value is divided into four dimensions, including functional value for performance, functional value for money, emotional value, and social value.

Functional value for performance is defined as evaluations of the quality and expected performance (Sweeney and Soutar, 2001). Lowe and Alpert (2015) found that perceived product innovativeness positively influences consumers' utilitarian attitudes. In their research, they defined utilitarian attitudes as consumers' evaluations of products' functionality. Accordingly, perceived product innovativeness has a positive effect on consumers' perceptions of the attributes and functions. Consumers may believe that innovative design, new or improved attributes can lead to a better experience with the products. Therefore, perceived product innovativeness positively influences consumers' perceived functional value for performance. Furthermore, Campbell et al. (2014) found that price/quality judgments have a positive effect on consumers' willingness to pay for local food. In this case, this research hypothesizes that the positive perceptions toward functional value for performance may lead to a high preference for payment. Accordingly, the perceived product innovativeness has a positive effect on functional value for performance, and the functional value for performance has a positive effect on willingness to pay. Hypothesis 2(a) is formulated: 
H2 (a): Perceived functional value for performance positively mediates the relationship between perceived product innovativeness and consumers' willingness to pay.

Functional value for money is defined as the utility derived from the comparison of benefits and costs (Sweeney and Soutar, 2001). Kim et al. (2017) used the term "monetary worth" to describe consumers' perceptions of functional value for money and found that this value can be significantly influenced by innovative design, which is a type of product innovation. As the new or improved attributes and functions may provide better customer experience, the consumers may prefer to pay more for these innovative characteristics. Accordingly, perceived product innovativeness may have a positive effect on consumers' perceived functional value for money. Given that perceived price significantly influences people's paying behavior (Le Gall-Ely, 2009), the positive perceived functional value for money may encourage consumers to pay more. Considering the relationship between perceived product innovativeness and functional value for money and the relationship between perceived value and willingness to pay, Hypothesis 2(b) is formulated:

H2 (b): Perceived functional value for money positively mediates the path between perceived product innovativeness and consumers' willingness to pay.

Since people tend to seek novelty for satisfying stimulation need, independence toward others' communicated experience and uniqueness (Roehrich, 2004), products with high innovativeness may support consumers in generating positive emotions or feelings. Thus, the level of emotional value that is defined as the feelings or emotions generated toward a product (Sweeney and Soutar, 2001) will increase as consumers perceive that they acquire novel products. Furthermore, Li et al. (2012) indicated the significant relationship between perceived emotional value and willingness to pay. Therefore, consumers' emotional value may play the role of a bridge in the relationship between perceived product innovativeness and willingness to pay. Hypothesis $\mathrm{H} 2(\mathrm{c})$ is proposed:

H2 (c): Emotional value positively mediates the effect of perceived product 
innovativeness on consumers' willingness to pay.

Social value refers to consumers' perception of to what extent a product enhances his or her social self-concept. The simple definition of self-concept is a person's perception of himself (Shavelson et al., 1976). Given the needs of being unique and independent in communication with others (Roehrich, 2004), innovativeness may help a person achieve his unique and independent image in the eyes of others. In other words, innovativeness may serve to improve a person's self-concept. Goldsmith et al. (1999) also suggested that individuals with fashion innovativeness report a positive self-image. As Sirgy (1985) regarded product image as one of the functions of selfconcept, consumers may be attracted by innovative products to address the discrepancy between their actual self-concept and an ideal uniqueness-image. Therefore, it can be inferred that perceived product innovativeness may have a positive effect on consumers' social value. Furthermore, Kang et al. (2012) demonstrated that social identity determines people's willingness to pay for the green initiatives of a hotel. Regarding the products as high social value ones in a person's mind, the person may prefer to pay more for the enhancement of the self-concept. In this case, the positive social value may prompt consumers to pay more. Given the hypotheses that state product innovativeness has a positive effect on social value and social value positively influences consumers' willingness to pay, this research asks whether social value serves as a bridge in the relationship between perceived product innovativeness and willingness to pay.

H2 (d): Social value positively mediates the path of perceived product innovativeness affects willingness to pay.

\subsection{Perceived product innovativeness and consumer innovativeness}

Consumer innovativeness that highlights its independence against the product category, communicated experience, and situational effects, is defined as the extent to which an individual can accept new knowledge and make innovative decisions without being influenced by others (Midgley and Dowling, 1978). Accordingly, high-level consumer innovativeness stimulates an innovative orientation. Jeong et al. (2017) 
studied the relationship between perceived novelty and consumer innovativeness and found that consumer innovativeness significantly influences consumers' perceived novelty regarding wearable devices. Different from perceived novelty, which pays attention to new attributes, perceived product innovativeness identifies not only the novel product features but also the improved and better functions (Lowe and Alpert, 2015). To satisfy the needs for independence when communicating with others, the person with a higher degree of consumer innovativeness may more expect to access advanced knowledge and information, which may lead to a higher sensitive cognition of the innovative attributes, including both novelty and improvement. Therefore, this research hypothesizes that consumer innovativeness may positively influence consumers' perceived product innovativeness.

H3: Consumer innovativeness contributes to perceived product innovativeness.

\subsection{Consumer innovativeness and consumers' willingness to pay}

Consumer innovativeness is considered as the antecedent of change of consumers' attitudes toward innovation. Truong (2013) pointed out the positive effect of consumer innovativeness on perceived value and attitude toward innovation. Besides, in technology adoption research, motivated consumer innovativeness has been verified to be positive to change of attitude to technology acceptance (e.g., Hwang, et al., 2019). Since the positive relationship between attitude and behavioral intention has been asserted in the literature, we assume that consumer innovativeness may influence behaviors. In this study, as consumers have great attention to chase innovative things, they will positively perceive the high-technological smart toys and tend to own ones. Therefore, the $\mathrm{H} 4$ is formulated:

H4: Consumer innovativeness contributes to consumers' willingness to pay.

\subsection{Consumer innovativeness as moderator}

Existing research regards consumer innovativeness as a dominant factor influencing consumers' adoption behavior (Chao et al., 2012; Lassar et al., 2005; Im et 
al, 2003). These results suggest that innovative consumers can easily adopt new products, services and technologies. Therefore, innovative consumers may generate more positive attitudes toward the innovative attributes of a product than conservative consumers may. The findings of Truong (2013) and Hong et al. (2017) also revealed the positive effect of higher consumer innovativeness on higher perceived value for money, hedonic value, and utilitarian value. Regarding the relationship between perceived innovativeness and perceived value, consumers who are inclined to innovation will be positively influenced by product innovation sensitively. Accordingly, the level of consumer innovativeness, which serves as an individual's characteristic (Midgley and Dowling, 1978), may positively influence the relationship between perceived product innovativeness and perceived value. Therefore, this research hypothesizes that the relationship between perceived product innovativeness and each dimension of perceived value, including functional value for performance, functional value for money, emotional value, and social value, is positively moderated by consumer innovativeness.

H5(a): As the level of consumer innovativeness increases, the influence of perceived product innovativeness on functional value for performance becomes stronger.

H5(b): As the level of consumer innovativeness increases, the influence of perceived product innovativeness on functional value for money becomes stronger.

H5(c): As the level of consumer innovativeness increases, the influence of perceived product innovativeness on perceived emotion value becomes stronger.

H5(d): As the level of consumer innovativeness increases, the influence of perceived product innovativeness on perceived social value becomes stronger. 


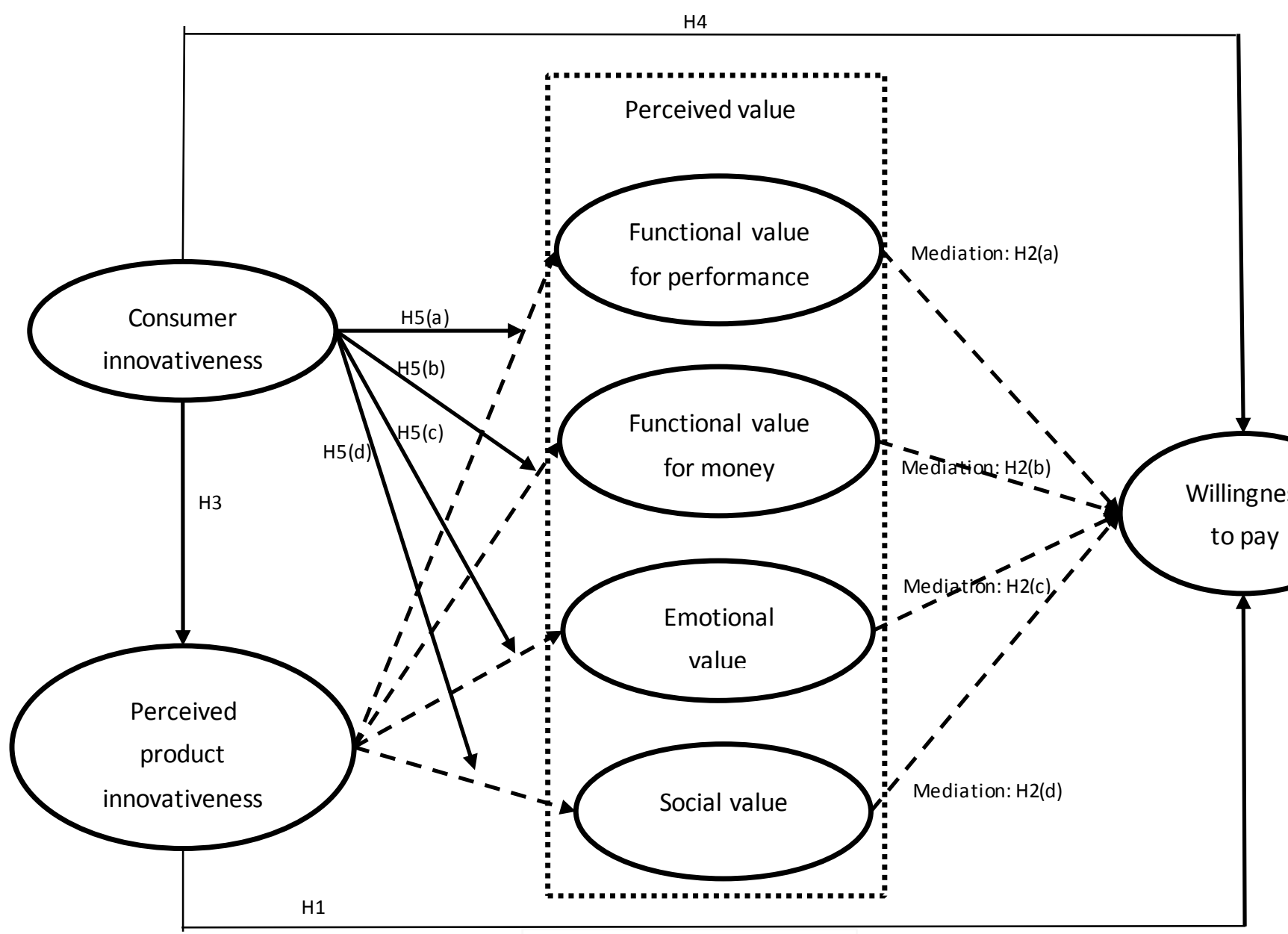

Figure1: Research model

\section{Research method}

\subsection{Research context}

This study was conducted in the Chinese context. China has a promising market for the toy industry. Digital Journal (2018) and China's Toy Market (2018) reported that there had been a vast and continuous increase in retail sales of toys in China in recent years. For example, the sales of toys in the Chinese market have been rising from RMB111.8 billion in 2012 to RMB276.5 billion in 2017 and the increase will continue. Subsequently, as the average incomes of people increases at a rate of 7-10\% annually, the demand for toys of Chinese people is changing from traditional toys to intelligent toys, innovative electronic toys, decorative cloth toys, and up-market plush toys. 
Besides, the potential market in China is numerous because of the two-child policy. Since 2016, the Chinese government has announced the two-child policy that will make the number of newborns will be between 17.5 million and 21 million annually. This increasing number of newborns means huge demand and positive toy market prospects. Finally, since Chinese parents pay great attention to children's early education, they prefer to buy educational toys to inspire their children's imagination and innovation, hoping to make their children superior at school. Therefore, smart toys that cultivate people's intelligence are becoming more popular. Since the Chinese market is a huge and promising market for the smart toy industry, the findings from this study are of significance.

\subsection{Measurements}

Considering consumers' perceptions toward innovativeness are individual attitudes and cannot be observed clearly by a third party. Thus, this study conducted quantitative research by self-reported online questionnaires. The questionnaires consisted of three parts, including (1) an introduction to the Dash robot in the form of text, pictures, and a video from the producer's website, (2) demographic information of the respondents (i.e., income, gender, age, and education level), and (3) scales of proposed variables, referring to perceived product innovativeness, perceived value, consumer innovativeness, and willingness to pay. Before answering the questions, the respondents were provided with basic acknowledge about the function of the target smart toy case from the text, pictures and a video. Likert-scales were adopted to measure the attitudes of respondents in terms of perceived value, consumer innovativeness and perceived product innovativeness. Previous studies have applied 5or 7-points scales in survey research. However, this might lead to invalid responses from participants in the Eastern cultural context in which people mostly hold moderate views (Tsang, 2011). To avoid any improper influence of such a "naturally moderate attitude", all Chinese participants were required to answer 6-point scales (i.e., from 1 for strongly disagree to 6 for strongly agree) according to the suggestions of Kurisu (2015). 
With the help of two bilingual professors, all the scales were modified and translated from existing research based on the advice of Brislin (1986) to ensure translation validity. Besides, a pretest among 20 students from Xi'an JiaotongLiverpool University was conducted on $24^{\text {th }}$ May 2018 to ensure the validity of the questionnaire.

Perceived product innovativeness was measured by three questions adapted from Fu and Elliott (2013). Consumer innovativeness was measured by four questions modified from Agarwal and Prasad (1998) and Citrin et al. (2000). Furthermore, based on the study of Sweeney and Soutar (2001), the perceived value scale had fifteen items, including four-item functional value for performance sub-scale, four-item emotional value sub-scale, three-item functional value for money sub-scale, and four-item social value sub-scale. The two most common methods of observing the willingness to pay are the open-ended questions and closed-ended questions with dichotomous choice questioning methods. Kealy and Turner (1993) found that there were no significant differences in results between these two question formats. Accordingly, this research adopted the open-ended question. The researcher divided the answers into six grades in the order of size, where 1 represents the group of lowest given price and 6 represents the group of the highest given price. To be specific, the results of "willingness to pay" were divided into intervals (less than 460 RMB, 461-920 RMB, 922-1380 RMB, 1381$1840 \mathrm{RMB}, 1841-2300 \mathrm{RMB}$, over $2300 \mathrm{RMB}$ ) and transferred into a 6-point Likert scale. Appendix A shows the measurements of the variables.

\subsection{Sampling and data collection}

A purposive sampling was adopted to determine the target toy from the list of technology toys of the year (i.e., Air Hogs Connect: Mission Drone, CodeGamer, LUMI, MOTA JETJAT Ultra Streaming Nano Drone, Sky Viper Hover Racer, Wonder Workshop's Dash \& Dot, and Zoomer Chimp) from the Toy Industry Association's website (Appell, 2017). The technology toy of the year list ranked the toys with 
different kinds of advanced technology. To avoid the influence of personal preference toward specific features on willingness to pay, the Dash robot, a smart toy with many features, was chosen to be the target smart toy.

Among all the smart toys, the Dash robot is the most popular one. This robot, made by the Wonder Workshop team, first hit the market in 2014. With the help of sensors, Dash knows how to choose running route, to detect the sounds, and to communicate with other robots as it saw them. This robot can move, light up, dance, avoid obstacles, make sounds, and react to voices. Furthermore, the robot is equipped with apps that provide games, tasks, and challenges of the different degrees of diffic ulty to appeal to all ages. Users explore programming to control the robot so that this smart toy contributes to users' learning of coding. However, this robot is only sold online through the Apple online store and Amazon. This research selected the Dash robot as the case for several reasons as followed. First, the online sales model relieves the time pressure and saves transportation costs to buy the product for consumers so that people can obtain the robot without significant effort. Second, online sales channels are Apple and Amazon, which are known by most people. Third, this robot is still innovative for consumers in many countries.

Since the previous researchers have regarded the willingness to pay as a more profound commitment than adoption behavior (e.g., Huang et al., 2006; Fu and Ellio tt, 2013), the population of this research was targeted as the people who accepted the appearance of smart toys. Therefore, two questions ("What do you think about smart toys entering into the market?" and "Would you be willing to buy a smart toy for your children or friends' and relatives' children, if you did not consider the price?" ) were included in the questionnaire to filter the samples. The research excluded the participants who had no idea or a negative idea about the emergence of smart toys and people who were not willing to buy toys for children. Besides, to help people respond to the questions accurately, the researcher gave the definitions quoted from Kara et al. (2013) and Kara et al. (2014) before the question. The explanation was as follows:

"Smart toys are toys that connect with digital technologies. Designers 
incorporate wireless communication capabilities, sensors, and actuators into the products so that the toys can respond to the users and integrate the physical world and the virtual world. A typical example is a robot."

The link to the online questionnaire was shown on the Wenjuanxing official website, one of the biggest survey websites in China. According to the suggestions of Krejcie and Morgan (1970), the sample size increases with the population size at a diminishing rate and remains relatively constant at 384 with a 95\% confidence level and a 5\% confidence interval. Considering invalid participates and around 5\% nonresponse rates (Meterko et al., 2015), we stopped collecting questionnaires when the click rates of the questionnaire arrive at 450 . All the people who go to the Wenjuanxing website could see the questionnaire link and fill the questionnaire voluntarily. Finally, 432 complete questionnaires were withdrawn. After filtering the ineligible participates, 399 questionnaires were valid, including 201 males and 198 females. Appendix B shows the demographic information of the respondents. The respondents were from different provinces and regions of China (e.g. Beijing, Shanghai, Shanxi, Yunnan, Guangdong, Anhui and Lanzhou). Most of them claimed that they obtained or were going to obtain higher education degrees, including associate college qualifications (9.0\%, $n=36)$, bachelor's degrees $(53.9 \%, n=215)$, master's degrees $(27.6 \%, n=110)$, or doctorate's degrees $(4.5 \%, \mathrm{n}=18)$. Among these respondents, around $29.6 \%$ earned more than $14000 \mathrm{RMB}$ per month. The ages of these respondents were concentrated from 23 to $40(23-28,34.1 \%, n=136 ; 29-34,30.6 \%, n=122 ; 35-40,22.3 \%, n=89)$. Based on the report from the National Bureau of Statistics of China in 2015, the most three age internals of fertility rate for the first child were 20-24 (40.17\%o), 25-29(41.55\%o), and 30-34(14.98\%o). Furthermore, people who were 25-29 years old and 30-34 years old had more tendency to have a second child. Given the "two-children" policy in China, it can be induced that the people between 20 to 34 years old were the main group of children's and toddlers' parents. Accordingly, the respondents whose ages were between 23 and 40 were the main consumers of smart toys. Therefore, we assumed that the samples could be regarded as representative for studying smart toys in China. 


\section{Results}

\subsection{Des criptive statistics and correlations}

This study applied SPSS 22.0 and Mplus 6.0 for the measurement model and structural model analysis. The researcher first used SPSS software to conduct descriptive statistics and correlation analysis. The K-S test showed that the data were non-normally distributed ( $\mathrm{p}$ value $=0.000<0.5$ ); therefore, the Spearman correlation was applied. Table 1 shows that the variables were positively correlated $(p<0.05)$. Perceived product innovativeness was positively correlated with willingness to pay $(r=0.237, p<0.01)$; Perceived product innovativeness was positively correlated with quality $(r=0.703$, $\mathrm{p}<0.01)$, emotion $(\mathrm{r}=0.668, \mathrm{p}<0.01)$, price $(\mathrm{r}=0.565, \mathrm{p}<0.01)$, social value $(\mathrm{r}=0.620$, $\mathrm{p}<0.01)$ and consumer innovativeness $(\mathrm{r}=0.524, \mathrm{p}<0.01)$; and willingness to pay was positively correlated with quality $(\mathrm{r}=0.197, \mathrm{p}<0.01)$, emotion $(\mathrm{r}=0.165, \mathrm{p}<0.01)$, price $(\mathrm{r}=0.207, \mathrm{p}<0.01)$, social value $(\mathrm{r}=0.178, \mathrm{p}<0.01)$.

Table 1 Descriptive statistics and correlations

\begin{tabular}{lllllllll}
\hline & Mean & SD & 1 & 2 & 3 & 4 & 5 & 6 \\
PI & 4.656 & 1.092 & & & & & & \\
QUA & 4.489 & 0.993 & $0.703^{* *}$ & & & & & \\
EMO & 4.598 & 0.991 & $0.668^{* *}$ & $0.778^{* *}$ & & & & \\
PRI & 4.127 & 1.272 & $0.565^{* *}$ & $0.670^{* *}$ & $0.655^{* *}$ & & & \\
SOC & 4.332 & 1.114 & $0.620^{* *}$ & $0.751^{* *}$ & $0.720^{* *}$ & $0.634^{* *}$ & & \\
WTP & 2.790 & 1.966 & $0.237^{* *}$ & $0.197^{* *}$ & $0.165^{* *}$ & $0.207^{* *}$ & $0.178^{* *}$ & \\
CI & 4.418 & 1.104 & $0.524^{* *}$ & $0.672^{* *}$ & $0.607^{* *}$ & $0.622^{* *}$ & $0.626^{* *}$ & $0.225^{* *}$ \\
\hline
\end{tabular}

Note: $\mathrm{N}=399 . * \mathrm{p}<0.05 ; * * \mathbf{p}<0.01$.

\subsection{Measurement model analysis}


Mplus 6.0 and SPSS was used for confirmatory factor analysis (CFA) to assess the reliability and validity. We first set up a six-latent-factor model (M0: PI, QUA, EMO, PRI, SOC, and CI) and then compared the model M0 with other alternative models, including five-latent-factor model (M1: PI+ QUA, EMO, PRI, SOC and CI), fourlatent-factor model (M2: PI+ QUA, EMO+ PRI, SOC and CI), three-latent-factor model (M3: PI+ QUA, EMO+ PRI, SOC+ CI), two-latent-factor model (M4:PI+ QUA, EMO+ $\mathrm{PRI}+\mathrm{SOC}+\mathrm{CI})$, and one-latent-factor model $(\mathrm{M} 5: \mathrm{PI}+\mathrm{QUA}+\mathrm{EMO}+\mathrm{PRI}+\mathrm{SOC}+\mathrm{CI})$. As Table 2 shown, the results of six-latent-factor model (Chi-Square Test of Model Fit $=370.877 ; \mathrm{CFI}=0.970 ; \mathrm{TLI}=0.964 ; \mathrm{RMSEA}=0.031 ; \mathrm{SRMR}=0.048)$ revealed superior fit and good discriminative validity.

Table 2 Confirmatory factor analysis

\begin{tabular}{ccccccc}
\hline Model & $\chi 2$ & $D f$ & CFI & TLI & SRMR & RMSEA \\
Quality & $>0$ & & $>0.9$ & $>0.9$ & $<0.08$ & $<0.08$ \\
Criteria & & & & & & \\
(M0) & 370.877 & 194 & 0.970 & 0.964 & 0.031 & $0.048[0.040,0.055]$ \\
(M1) & 512.890 & 199 & 0.947 & 0.938 & 0.038 & $0.063[0.056,0.070]$ \\
(M2) & 547.867 & 203 & 0.942 & 0.933 & 0.039 & $0.065[0.059,0.072]$ \\
(M3) & 926.125 & 206 & 0.878 & 0.863 & 0.049 & $0.094[0.088,0.100]$ \\
(M4) & 1008.108 & 208 & 0.864 & 0.849 & 0.051 & $0.098[0.092,0.104]$ \\
(M5) & 1447.408 & 209 & 0.790 & 0.768 & 0.070 & $0.122[0.116,0.128]$ \\
\hline
\end{tabular}

Furthermore, table 3 showed that Cronbach's Alpha ranged from 0.800 to 0.914 and composite reliability values ranged from 0.872 to 0.946 , which were higher than 0.70 (Bagozzi and Yi, 2012), suggesting a good level of reliability. All of the AVE values were higher than 0.5 and all of the correlations between each pair of latent constructs were less than the square root of the AVE for each construct, as table 3 and table 4 shown, supporting the acceptable convergent validity and discriminant validity (Fornell and Larcker, 1981). 
Table 3: Reliability and validity

\begin{tabular}{|c|c|c|c|c|}
\hline Construct & Items & $\begin{array}{c}\text { Cronbach's } \\
\text { Alpha }\end{array}$ & $\begin{array}{l}\text { Composite } \\
\text { Reliability }\end{array}$ & AVE \\
\hline \multirow{5}{*}{$\begin{array}{l}\text { Customer innovativeness } \\
\text { (CI) }\end{array}$} & CI1 & 0.880 & 0.918 & 0.736 \\
\hline & $\mathrm{CI} 2$ & & & \\
\hline & $\mathrm{CI} 3$ & & & \\
\hline & CI4 & & & \\
\hline & CI5 & & & \\
\hline \multirow[t]{8}{*}{ Emotional value (EMO) } & EMO & 0.845 & 0.896 & 0.684 \\
\hline & 1 & & & \\
\hline & EMO & & & \\
\hline & 2 & & & \\
\hline & EMO & & & \\
\hline & 3 & & & \\
\hline & EMO & & & \\
\hline & 4 & & & \\
\hline \multirow{3}{*}{$\begin{array}{l}\text { Perceived product } \\
\text { Innovativeness (PI) }\end{array}$} & PI1 & 0.867 & 0.919 & 0.790 \\
\hline & PI2 & & & \\
\hline & PI3 & & & \\
\hline \multirow{3}{*}{$\begin{array}{l}\text { Function value for money } \\
\text { (PRI) }\end{array}$} & PRI1 & 0.914 & 0.946 & 0.853 \\
\hline & PRI2 & & & \\
\hline & PRI3 & & & \\
\hline \multirow{7}{*}{$\begin{array}{l}\text { Functional } \\
\text { quality } \\
\text { (QUA) }\end{array}$} & QUA & 0.861 & 0.906 & 0.707 \\
\hline & 1 & & & \\
\hline & QUA & & & \\
\hline & 2 & & & \\
\hline & QUA & & & \\
\hline & 2 & & & \\
\hline & QUA & & & \\
\hline
\end{tabular}


4

Social value (SOC)

SOC1

0.800

0.872

0.632

SOC2

SOC3

SOC4

Table 4: Fornell-Larcker Criterion

\begin{tabular}{lcccccc}
\hline & CI & EMO & PRI & QUA & PI & SOC \\
CI & $\mathbf{0 . 8 5 8}$ & & & & & \\
EMO & 0.516 & $\mathbf{0 . 8 2 7}$ & & & & \\
PRI & 0.446 & 0.714 & $\mathbf{0 . 8 8 9}$ & & & \\
QUA & 0.545 & 0.663 & 0.575 & $\mathbf{0 . 9 2 4}$ & & \\
PI & 0.582 & 0.786 & 0.711 & 0.661 & $\mathbf{0 . 8 4 1}$ & \\
SOC & 0.555 & 0.703 & 0.622 & 0.648 & 0.746 & $\mathbf{0 . 7 9 5}$ \\
\hline
\end{tabular}

\subsection{Hypotheses testing}

\subsubsection{Direct effects}

A linear regression method was conducted with Mplus 6.0 to examine the direct effects among consumer innovativeness, perceived product innovativeness, and willingness to pay. The results (Estimate $=0.190$, S.E. $=0.066$, Est./S.E $=2.896$, Pvalue $=0.004<0.05 ;$ Estimate $=0.114$, S.E. $=0.052$, Est. $/ \mathrm{S} . \mathrm{E}=2.189, \mathrm{P}-\mathrm{value}=$ $0.029<0.05$ ) respectively showed that perceived product innovativeness and consumer innovativeness could predict consumers' willingness to pay, supporting the hypothesis 1 and 4. Furthermore, the result (Estimate $=0.444$, S.E. $=0.050$, Est./S.E $=8.814$, Pvalue $=0.000<0.05)$ supports hypothesis 3 , suggesting the consumers innovativeness have a positive effect on consumers' perceived product innovativeness.

\subsubsection{Mediation analysis}


The indirect effect analysis of Mplus showed that only social value played a mediating role in the path of perceived product innovativeness on willingness to pay (Estimate $=$ 0.238 , S.E. $=0.044$, Est./S.E $=5.348, \mathrm{P}$-value $=0.000<0.05)$. To further verify the mediation, the SPSS PROCESS program was used to test the mediating effect with 5000-time bootstrapping (Bolin et al., 2013; Preacher and Hayes, 2008). The results were shown in table 5 . The $95 \%$ confidence interval for direct effect $[0.0930,0.5956]$ that including 0 and the $95 \%$ confidence interval for indirect effect [0.2919, 0.6317] that excluding 0 suggest that social value positively mediates the effect of perceived product innovativeness on willingness to pay, supporting hypothesis 2(d). Furthermore, the $p$-value of the Sobel test $(p=0.000)$ also confirms the mediation role of social value. However, as table 5 shows, the results reject $\mathrm{H} 2(\mathrm{a}), \mathrm{H} 2(\mathrm{~b})$, and $\mathrm{H} 2(\mathrm{c})$, suggesting that the mediating effects of functional value for performance, functional value for money, and emotional value do not exist.

\begin{tabular}{|c|c|c|c|c|c|}
\hline \multirow{3}{*}{ Path } & \multirow{3}{*}{ Sobel test } & \multirow{3}{*}{ Bootstrapping $\beta$} & \multicolumn{3}{|c|}{ Confidence interval $(95 \%)$} \\
\hline & & & & & \multirow[t]{2}{*}{ _Mediation Effect } \\
\hline & & & Lower & Upper & \\
\hline $\mathrm{PI} \rightarrow \mathrm{QUA} \rightarrow \mathrm{WTP}$ & -0.1986 & -0.1986 & -0.4267 & -0.0088 & No \\
\hline $\mathrm{PI} \rightarrow \mathrm{PRI} \rightarrow \mathrm{WTP}$ & 0.0514 & 0.0514 & -0.0900 & 0.1768 & No \\
\hline $\mathrm{PI} \rightarrow \mathrm{EMO} \rightarrow \mathrm{WTP}$ & -0.1939 & -0.1939 & -0.4086 & 0.0138 & No \\
\hline $\mathrm{PI} \rightarrow \mathrm{SOC} \rightarrow \mathrm{WTP}$ & $0.4588^{* * *}$ & 0.4588 & 0.2919 & 0.6317 & Partial mediation \\
\hline \multicolumn{6}{|c|}{ Note:***represents $\mathrm{P}<0.01$} \\
\hline
\end{tabular}




\subsubsection{Moderated mediation analysis}

Table 6 showed the results of regression approach conducted by Mplus 6.0. Based on the results, interaction between consumer innovativeness and perceived product innovativeness did not have effects on functional value for performance (Estimate= 0.088, S.E. $=0.053$, Est./S.E $=1.656, \mathrm{P}-$ value $=0.098>0.05)$, functional value for money $($ Estimate $=0.093$, S.E.$=0.054$, Est. $/ \mathrm{S} . \mathrm{E}=1.722, \mathrm{P}-\mathrm{value}=0.085>0.05)$, and emotional value $($ Estimate $=0.036$, S.E. $=0.045$, Est. $/ \mathrm{S} . \mathrm{E}=0.800, \mathrm{P}-\mathrm{value}=0.424>0.05)$, rejecting H5(a), H5(b), and H5(c). The final result (Estimate= 0.120, S.E. $=0.046$, Est./S.E= 2.608, P-value $=0.009<0.05)$ supports H5(d), suggesting that the effect of perceived product innovativeness on social value became stronger when the level of consumer innovativeness increased.

SPSS PROCESS 5000-time bootstrapping method was also applied to test the moderated mediation effect (Table 7). The results showed that only perceived social value plays moderated meditation on the effect of perceived product innovativeness on willingness to pay (the $95 \%$ confidence interval $=[0.0100,0.1090]$, excluding 0 ). To be specific, as consumer innovativeness maintained at a low-level (-1 SD), the indirect effect of perceived product innovativeness on willingness to pay via quality was not significant $(\beta=0.0222,95 \% \mathrm{CI}=[-0.1046,0.1409])$. Also, the effect of the path was not significant $(\beta=0.0288,95 \% \mathrm{CI}=[-0.1285,0.1916])$ as consumer innovativeness stayed at a high level (+1 SD). Subsequently, as consumer innovativeness maintained at a lowlevel (-1 SD), the indirect effect of perceived product innovativeness on willingness to pay via price was not significant $(\beta=0.0671,95 \% \mathrm{CI}=[-0.0022,0.1480])$. Also, the effect of the path was not significant $(\beta=0.0970,95 \% \mathrm{CI}=[-0.0054,0.2095])$ as consumer innovativeness stayed at a high level (+1 SD). Next, as consumer innovativeness maintained at a low-level (-1 SD), the indirect effect of perceived product innovativeness on willingness to pay via emotion was not significant $(\beta=$ $0.0126,95 \% \mathrm{CI}=[-0.1541,0.1227])$. Also, the effect of the path was not significant $(\beta=$ $-0.0140,95 \% \mathrm{CI}=[-0.1711,0.1377])$ as consumer innovativeness stayed at a high level (+1 SD). However, as consumer innovativeness maintained at a low-level (-1SD), the 
indirect effect of perceived product innovativeness on willingness to pay via social value was significant $(\beta=0.2225,95 \% \mathrm{CI}=[0.1236,0.3445])$. Also, the effect of the path was significant $(\beta=0.3427,95 \% \quad \mathrm{CI}=[0.2080,0.5018])$ as consumer innovativeness stayed at a high level (+1 SD). 
Table 6. Moderation effect test results.

\begin{tabular}{|c|c|c|c|c|c|c|}
\hline \multirow{5}{*}{$\begin{array}{l}\text { Interaction } \\
\text { effect }\end{array}$} & Esti & S. & Es & P- & Estim & \multirow[t]{5}{*}{ 95\% Conf. } \\
\hline & mat & E. & t./ & val & ate & \\
\hline & \multirow[t]{3}{*}{$\mathrm{e}$} & & S. & ue & (boots & \\
\hline & & & E. & & trappi & \\
\hline & & & & & ng) & \\
\hline \multirow[t]{3}{*}{ QUA*PI } & & 0. & & & 0.060 & {$[0.000,0.12$} \\
\hline & & 05 & & & & \multirow[t]{2}{*}{ 0] } \\
\hline & 88 & & 56 & 98 & & \\
\hline \multirow[t]{3}{*}{ PRI*PI } & & 0. & & & 0.081 & \multirow{3}{*}{$\begin{array}{c}{[-0.002} \\
0.156]\end{array}$} \\
\hline & 0.0 & 05 & 1.1 & 0.0 & & \\
\hline & 93 & & 22 & 85 & & \\
\hline \multirow[t]{3}{*}{ EMO*PI } & & 0. & & & 0.024 & {$[-$} \\
\hline & & 04 & 0.8 & & & \multirow{2}{*}{$\begin{array}{c}0.029,0.074 \\
]\end{array}$} \\
\hline & 50 & 5 & & 24 & & \\
\hline \multirow[t]{3}{*}{ SOC*PI } & & 0. & & & 0.103 & \multirow{3}{*}{$\begin{array}{l}{[0.036,} \\
0.170]\end{array}$} \\
\hline & & 04 & 2.0 & 0.0 & & \\
\hline & 2 & 6 & 08 & 09 & & \\
\hline
\end{tabular}

Table 7 Moderated mediation

\begin{tabular}{lccc}
\hline Hypotheses & Index & S.E. (boot) & $\mathbf{9 5 \%}$ Conf. \\
$\mathrm{PI} * \mathrm{CI} \rightarrow \mathrm{QUA} \rightarrow \mathrm{WTP}$ & 0.0031 & 0.0104 & {$[-0.0118,0.0329]$} \\
$\mathrm{PI} * \mathrm{CI} \rightarrow \mathrm{PRI} \rightarrow \mathrm{WTP}$ & 0.0128 & 0.0115 & {$[-0.0015,0.0473]$} \\
$\mathrm{PI} * \mathrm{CI} \rightarrow \mathrm{EMO} \rightarrow \mathrm{WTP}$ & -0.0004 & 0.0051 & {$[-0.0164,0.0069]$} \\
$\mathrm{PI} * \mathrm{CI} \rightarrow \mathrm{SOC} \rightarrow \mathrm{WTP}$ & 0.0529 & 0.0250 & {$[0.0100,0.1090]$} \\
\hline
\end{tabular}




\subsubsection{Serial multiple mediation test (From CI to WTP through PI and Perceived value)}

We also tested the multiple mediations from consumer innovativeness to the willingness to pay via perceived product innovativeness and perceived value. Table 8 showed that although consumer innovativeness had a positive direct effect on willingness to pay, the $95 \%$ confidence intervals for the indirect effect of CI on WTP via PI and QUA, EMO, PRI included 0, respectively. On the contrary, although the direct effect of CI on WTP was not significant, the $95 \%$ confidence intervals for the indirect effect of CI on WTP via PI and SOC were [0.0614, 0.1778], excluding 0. Therefore, PI and SOC mediated the path of CI on WTP.

Table 8. Multiple Mediator model

\begin{tabular}{lcccc}
\hline & \multicolumn{4}{c}{ Mediating test by PROCESS } \\
\cline { 2 - 5 } & Direct & $\mathbf{9 5 \%}$ & Indirect & $\mathbf{9 5 \%}$ Confidence \\
& effect & $\begin{array}{c}\text { Confidence } \\
\text { interval }\end{array}$ & effect & interval \\
& & & \\
$\mathbf{C I} \rightarrow \mathbf{P I} \rightarrow \mathbf{Q U A}$ & 0.3239 & {$[0.1136$,} & -0.0333 & {$[-0.1109,0.0345]$} \\
$\rightarrow \mathbf{W T P}$ & & $0.5342]$ & & \\
$\mathbf{C I} \rightarrow \mathbf{P I} \rightarrow \mathbf{P R I} \rightarrow \mathbf{W T}$ & 0.2523 & {$[0.0444$,} & 0.0144 & {$[-0.0231,0.0556]$} \\
$\mathbf{P}$ & & $0.4602]$ & & \\
$\mathbf{C I} \rightarrow \mathbf{P I} \rightarrow \mathbf{E M O} \rightarrow \mathbf{W}$ & 0.3215 & {$[0.1196$,} & -0.0427 & {$[-0.1141,0.0230]$} \\
$\mathbf{T P}$ & & $0.5233]$ & & \\
$\mathbf{C I} \rightarrow \mathbf{P I} \rightarrow \mathbf{S O C} \rightarrow \mathbf{W}$ & 0.1158 & {$[-0.0817$,} & 0.1127 & {$[0.0614,0.1778]$} \\
$\mathbf{T P}$ & & $0.3134]$ & & \\
\hline
\end{tabular}

\section{Discussion}

\subsection{Findings}

This study mainly explores the role of product innovation and consumer innovativeness in consumers' willingness to pay for new products in terms of smart toys. 
Evidence from the results indicates that both consumer innovativeness and perceived product innovativeness can directly influence consumers' willingness to pay. Given that perceived value is an important determinant of consumers' willingness to pay (e.g., Smith, 2012; Schindler, 2012; Monroe, 2002; Meehan, 2011), the researcher regards perceived value as a mediator in the research model. However, only social value, one of the dimensions of perceived value, can mediate the influence of perceived product innovativeness on consumers' willingness to pay.

Furthermore, this study investigates the relationship between consumer innovativeness, perceived product innovativeness, and perceived value. The results show that the high degree of perceived product innovativeness could improve consumers' perceived functional value for performance, perceived functional value for money, emotional value, and social value. These influences are moderated by consumer innovativeness. Additionally, perceived product innovativeness can be regarded as one of the consequents of consumer innovativeness.

\subsection{Theoretical contributions}

This research begins with the research question that "does product innovation influence consumers' willingness to pay." In past literature, the term "product innovation" mainly emerges in organizational studies. Our research opens a new insight into studying product innovation from the consumers' perspective. The results support the vital role of product innovation in consumers' buying behavior, which consists of the previous studies by organizational researchers that successful product innovation expands market share, increases market power, and improves market performance (e.g., Aksoy, 2017; Dhanora et al, 2018). In addition, our findings extend the previous research on consumers' buying behavior regarding innovative products. Most of the consumer researchers focus on the factors that encourage consumers' acceptance of innovation, for example, perceived usefulness and perceived ease of use (Davis, 1989), performance expectancy, effort expectancy, social influence, and subjective norms (Venkatesh et al., 2003). Such factors help organizations to achieve the success of product innovation. However, the existing studies ignore the influence of innovation 
itself. Given that people have the desire for novelty seeking and uniqueness (Roehrich, 2004), it can be assumed that the innovative attributes attract consumers. Our results support this assumption, suggesting that consumers will generate interest in a product if they recognize the new attributes of this product.

Furthermore, this research incorporates consumer innovativeness into the research model and adopts consumer innovativeness as a domain-specific concept in smart technology according to the suggestions of Midgley and Dowling (1993). The findings extend the consumer innovativeness theories by enriching the contents of the consequents of the domain-specific innovativeness. Summarizing by Bartels and Reinders (2011), the consequents of domain-specific innovativeness mainly involve various innovative behaviors, such as purchase intention, new product adoption, product attitude, and ownership of new products. Our results complement the willingness to pay as one of the innovative behaviors that can be influenced by consumers' domain-specific innovativeness. Additionally, our studies indicate that domain-specific innovativeness could lead consumers to generate favorable judgments on the products. In other words, the consumers' perceptions of the products can also be regarded as the consequents of domain-specific innovativeness. Therefore, future researchers may pay attention to the influence of consumer innovativeness on consumers' evaluations of innovative products.

This research also extends the consumers' acceptance models by adopting the willingness to pay as the dependent variables. Since the willingness to pay has been proposed, this construct is mainly studied in environmental consumption behavior and safety food buying behavior (Krystallis and Chryssochoidis, 2005). As the customerbased pricing strategy is a better alternative pricing strategy to set an initial price for the new products (Schindler, 2012), willingness to pay, which can be regarded as a reference value, is significant to the organizations. Researchers may pay attention to not only adoption behaviors but also the willingness to pay. Our findings that product innovation and consumer innovativeness could predict consumers' willingness to pay regarding the smart toys lay a solid foundation for future research of consumers' 
willingness to pay for the innovative products in the different domains.

Finally, our research obtains an interesting finding that should be noted by consumer researchers. The result shows that among the four dimensions of perceived value, only social value has a significant effect on consumers' willingness to pay. This is inconsistent with the previous perceived value research that quality, price, and emotional value could predict consumers' buying behavior (e.g., Campbell et al., 2014; Le Gall-Ely, 2009; Li et al., 2012). The difference in results may because of the specific research context. Our survey is conducted in China. Based on the existing research (e.g., $\mathrm{Li}$ and $\mathrm{Su}, 2007$; Bao et al., 2003), Chinese people regarded consumption more as a tool to serve higher-order social needs than as a simple activity. With the development of technology, Chinese people could share their daily life on social platforms, such as WeChat, Microblog, and Instagram. This may stimulate consumers to build an ideal social self-image on social platforms by sharing their consumption behavior. In this case, the social values of products may be more significant than before. Especially in terms of several non-necessities like smart toys, the social value may become the primary motivator for paying the high price. Accordingly, as the changeable of living standards and styles, it can be inferred that the traditional theories related to consumer values cannot apply to the complex context. Our findings encourage future researchers to pay attention to the specificity of the targeted product and the research context when studying consumer values.

\subsection{Practical contributions}

The study also gives some suggestions to the smart toys' manufacturers and sellers. First, the study verifies that perceived product innovativeness has a positive effect on consumers' willingness to pay. This encourages the manufacturers to add the new components into the products. Furthermore, as new products are announced in the market, the company should emphasize the unique and novel attributes of their products in the advertising to stimulate consumers' perceived product innovativeness, and thus to enhance consumers' willingness to pay. 
Second, according to the results that consumers with higher innovativeness will be more sensitive to the product innovation and also more positive to evaluate the innovative products, producers could clarify the market target more precisely and accurately. In terms of smart toys, market targeting can be aimed at those people who have high innovativeness traits regarding high technologies. Those consumers are easy to generate a favorable impression and positive evaluation of the new products. To discover and attract innovative customers, the company could place the newly released product in the retailers for free to try or hold free demo activities. In general, the consumer preferred to try are the people with high innovativeness.

Third, the results show that social value medicates the relationship between perceived product innovativeness and willingness to pay, suggesting that not only the manufacturers should pay attention to the product innovation but also the sellers should focus on the market strategies to improve products' social significance. In this case, the introduction of products and advertising could be more personalized and social network-orientated, for example, defining the new product as tools for social interaction and interpersonal communication.

\subsection{Limitations}

The current research has several limitations that could provide some suggestions for further research. To conduct the survey, the researcher selected the Dash robot as the case. However, smart toys have multiple categories in the market, and only studying one case may limit the results to extend to other types of smart toys. Further research can select multiple cases to get more generalizable conclusions in the survey when studying smart toys. Besides, this research uses a self-reporting method for consumers' willingness to pay. However, this method may give rise to common method bias. Therefore, further research can use both a self-reporting method and analyze the differences between the results of the two. Furthermore, the respondents in this research were Chinese people. Further research should be more diverse in scope. 


\section{Conclusion}

Although past literature has studied the smart toy, not enough research is conducted in this context from the perspective of consumer behavior and the Chinese context. This study enriches gaps in the literature on smart toys, consumer innovativeness and perceived value. We introduce the perceived product innovativeness and explain the mechanism of how consumers' attitudes toward innovation lead to the willingness to pay via perceived value. The online survey data from 399 Chinese consumers were analyzed with Mplus 6.0 and SPSS PROCESS. Results verify that consumer innovativeness leads to the willingness to pay via perceived product innovativeness. Furthermore, the study reveals that perceived social value has a mediating effect between perceived product innovativeness and willingness to pay. Consumer innovativeness is also verified to have a moderating effect between perceived product innovativeness and perceived social value. Besides, the study reveals the mediating effect of perceived product innovativeness and perceived social value on the path of consumer innovativeness and willingness to pay. Our findings provide some implications for future research and practice.

\section{Acknowledgment}

We are grateful to VC Research to support this research, with grant number VCR 0000001.

\section{References}

Agarwal, R., Prasad, J., 1998. A Conceptual and Operational Definition of Personal Innovativeness in the Domain of Information Technology. Inf. Syst. Res. 9 (2), 204-215. https://doi. org/10.1287/isre.9.2.204.

Ajzen, I., 1991. The theory of planned behavior. Organ. Behav. Hum. Decis. Process. 50 (2), 179-211. https://doi.org/10.1016/0749-5978 (91)90020-t. 
Aksoy, H., 2017. How do innovation culture, marketing innovation and product innovation affect the market performance of small and medium-sized enterprises (SMEs)? Technol. Soc. 51, 133-141. https://doi.org/10.1016/j.techsoc.2017.08.005.

Appell, A., 2017. 2017 Toy of the Year (TOTY) Award Finalists Unveiled by Toy Industry Association.

https://www.toyassociation.org/PressRoom2/News/2016_News/2017_Toy_of_the_Year_TO TY_Award_Finalists_Unveiled_by_Toy_Industry_Association.aspx (accessed on 13 November 2019).

Bao, Y., Zhou, K.Z., Su, C., 2003. Face consciousness and risk aversion: do they aff ect consumer decision-making? Psychol. Market. 20, 733 - 755.

Bartels, J., Reinders, M.J., 2011. Consumer innovativeness and its correlates: A propositional inventory for future research. J. Bus. Res. 64 (6), 601-609. https://doi. org/10.1016/j.jbusres.2010.05.002.

Bagozzi, R.P., Yi, Y. 2012. Specification, evaluation, and interpretation of structural equation models. J. Acad. Market. Sci.,40(1),8 - 34. https:/doi.org/10.1007/s11747-011-0278-x

Bolin, J.H. Hayes, Andrew F., 2013. Introduction to Mediation, Moderation, and Conditional Process Analysis: A Regression-Based Approach. New York, NY: The Guilford Press. J. Educ. Meas. 2014, 51, 335 - 337.

Brislin, R.W., 1986. The wording and translation of research instrument, in: Lonner, W.J., Berry, J.W. (Eds.), Field Methods in Cross-Cultural Research. Sage, CA, USA, pp. 137-164. 
Cagiltay, K., Kara, N., Aydin, C.C., 2014. Smart Toy BasedLearning, in: Spector, J. M., Merrill, M. D., Elen, J., Bishop, M.J. (Eds.), Handbook of Research on Educational Communications and Technology. Springer, New York, pp. 703-711.

Calantone, R., di Benedetto, C.A., Bhoovaraghavan, S., 1994. Examining the Relationship Between Degree of Innovation and New Product Success. J. Bus. Res. 30 (2), 143-148. https://oi.org/10.1016/0148-2963(94)90033-7.

Campbell, J., DiPietro, R.B., Remar, D., 2014. Local foods in a university setting: Price consciousness, product involvement, price/quality inference and consumer's willingness-to-pay. Int. J. Hosp. Manag. 42, 39-49. https://doi.org/10.1016/j.ijhm.2014.05.014.

Chandy, R.K., Tellis, G.J., 1998. Organizing for radical product innovation: the overlooked role of willingness to cannibalize. J. Mark. Res. 35 (4), 474-487. https://doi.org/10.2307/3152166.

Chang, C., Dibb, S., 2012. Reviewing and conceptualising customer-perceived value. Market. Rev. 12 (3), 253-274. https://doi.org/10.1362/146934712x13420906885395.

Chao, C.W., Reid, M., Mavondo, F.T., 2012. Consumer innovativeness influence on really new product adoption. Aust. Mark. J. 20(3), 211-217. https://doi.org/10.1016/j.ausmj.2012.02.001.

China's Toy Market, 2018. Hong Kong Trade development Council. http://china-traderesearch.hktdc.com/business-news/article/China-Consumer-Market/China-s-toymarket/ccm/en/1/1X000000/1X002MRF.htm (accessed 17 April 2019).

Citrin, A.V., Sprott, D.E., Silverman, S.N., Stem, D.E., 2000. Adoption of Internet shopping: The role of consumer innovativeness. Ind. Manage. Data Syst. 100 (7), 294-300. 
https://doi.org/10.1108/02635570010304806.

Davis, F.D., 1989. Perceived usefulness, perceived ease of use, and user acceptance of information technology. MIS Q. 13(3), 318-330. https://doi. org/10.2307/249008.

Dhanora, M., Sharma, R., Khachoo, Q., 2018. Non-linear impact of product and process innovations on market power: A theoretical and empirical investigation. Econ. Model. 70, 6777. https://doi.org/10.1016/j.econmod.2017.10.010.

Digital Journal, 2018. Global Smart Toys Market Creat a New Milestone \$ 5,410.00 Million by 2024. http://www.digitaljournal.com/pr/4250989 (accessed 17 April 2019).

Ekin, C.C., Cagiltay, K., Karasu, N., 2018. Effectiveness of smart toy applications in teaching children with intellectual disability. J. Syst. Architect. 89, 41-48. https://doi.org/10.1016/j. sysarc.2018.07.001.

Fishbein, M., Ajzen, I. 1975. Belief, attitude, intention, and behavior: an introduction to theory and research. Addison-Wesley, Reading.

Fornell, C., Larcker, D.F.1981. Evaluating structural equation models with unobservable variables and measurement error. J. Mark. Res., 18,39 50.https://doi.org/10.1177/002224378101800312

Fu, F.Q., Elliott, M.T., 2013. The Moderating Effect of Perceived Product Innovativeness and Product Knowledge on New Product Adoption: An Integrated Model. J. Market. Theory Practice 21(3), 257-272. https://doi.org/10.2753/mtp1069-6679210302.

Goldsmith, R.E., Hofacker, C.F., 1991. Measuring Consumer Innovativeness. J. Acad. Mark. 
Sci. 19(3), 209-221. https://doi.org/10.1007/bf02726497.

Goldsmith, R.E., Moore, M.A., Beaudoin, P., 1999. Fashion innovativeness and self-concept: a replication. J. Prod. Brand Manag. 8(1), 7-18. https://doi.org/10.1108/10610429910257904.

Hasbro, 2005. Hasbro Furby 59294 Care Manual. https:/www.manualslib.com/manual/256736/Hasbro-Furby-59294.html\#manual (accessed $7^{\text {th }}$ October 2019).

Hasbro, 2012. FURBISH DICTIONARY. http://www.furbymanual.com/manuals/FurbishD ictionary.pdf (accessed $7^{\text {th }}$ October 2019).

Hidrue, M.K., Parsons, G.R., Kempton, W., Gardner, M.P., 2011. Willingness to pay for electric vehicles and their attributes. Resour. Energy Econ. 33 (3), 686-705. https://doi.org/10.1016/j.reseneeco.2011.02.002.

Hirunyawipada, T., Paswan, A.K., 2006. Consumer innovativeness and perceived risk: implications for high technology product adoption. J. Consum. Mark. 23 (4), 182-198. https://doi.org/10.1108/07363760610674310.

Hoffmann, S., Soyez, K., 2010. A cognitive model to predict domain-specific consumer innovativeness. J. Bus. Res. 63 (7), 778-785. https:/doi.org/10.1016/j.jbusres.2009.06.007.

Hong, J.C., Lin, P.H., Hsieh, P.C., 2017. The effect of consumer innovativeness on perceived value and continuance intention to use smartwatch. Comput. Hum. Behav. 67, 264-272. https://doi.org/10.1016/j.chb.2016.11.001.

Huang, J.k., Qiu, H., Bai, J., Pray, C., 2006. Awareness, acceptance of and willingness to buy 
genetically modified foods in Urban China. Appetite, 46(2), 144-151. https://doi.org/10.1016/j.appet.2005.11.005.

Hultman, M., Kazeminia, A., Ghasemi, V., 2015. Intention to visit and willingness to pay premium for ecotourism: The impact of attitude, materialism, and motivation. J. Bus. Res. 68(9), 1854-1861. https $/ /$ doi.org/10.1016/j.jbusres.2015.01.013.

Hung, P.C.K., Tang, J.K.T., Kanev, K., 2017. Introduction, in: Computing in Smart Toys. Springer International Publishing, Cham, pp. 1-5.

Hwang, J., Kim, H., Kim, W. 2019. Investigating motivated consumer innovativeness in the context of drone food delivery services. J. Hosp. Tour. Manage., 38, 102-110. https://doi.org/10.1016/j.jhtm.2019.01.004

Im, S., Bayus, B.L., Mason, C.H., 2003. An Empirical Study of Innate Consumer Innovativeness, PersonalCharacteristics, and New-Product Adoption Behavior. J. Acad. Mark. Sci. 31(1), 61-73. https $/ /$ doi.org/10.1177/0092070302238602.

Jedidi, K., Jagpal, S., 2009. Willingness to Pay: Measurement and Managerial Implications, in: Rao, V.R. (Eds.), Handbook of Pricing Research in Marketing. Edward Elgar, UK, pp. 37-60.

Jeong, S.C., Kim, S.H., Park, J.Y., Choi, B., 2017. Domain-specific innovativeness and new product adoption: A case of wearable devices. Telemat. Inform. 34(5), 399-412. https://doi.org/10.1016/j.tele.2016.09.001.

Kahn, K.B., 2018. Understanding innovation. Bus. Horiz. 61 (3), 453-460. https://doi.org/10.1016/j.bushor.2018.01.011. 
Kang, K.H., Stein, L., Heo, C.Y., Lee, S., 2012. Consumers' willingness to pay for green initiatives of the hotel industry. Int. J. Hosp. Manag. 31(2), 564-572. https://doi. org/10.1016/j.ijhm.2011.08.001.

Kara, N., Aydin, C., Cagiltay, K., 2013. Investigating the Activities of Children toward a Smart Storytelling Toy. Educ. Technol. Soc. 16(1), 28-43.

Kara, N., Aydin, C.C., Cagiltay, K., 2014. Design and Development of a Smart Storytelling Toy. Interact. Learn. Environ. 22(3), 288-297. https://doi.org/10.1080/10494820.2011.649767.

Kazeminia, A., Hultman, M., Mostaghel, R., 2016. Why pay more for sustainable services? The case of ecotourism. J. Bus. Res. 69(11), 4992-4997. https://doi.org/10.1016/j.jbusres.2016.04.069.

Kealy, M.J., Turner, R.W., 1993. A test of the equality of closed-ended and open-ended contingent valuations. Am. J. Agr. Econ. 75(2), 321. https://doi.org/10.2307/1242916.

Kim, S.J.,Kim, K.H., Choi, J., 2017. The Role of Design Innovation in Understanding Purchase Behavior of Augmented Products. J. Bus. Res. 99, 354-362. https://doi.org/10.1016/j.jbusres.2017.09.047.

Kleinschmidt, E.J., Cooper, R.G., 1991. The impact of product innovativeness on performance. J. Prod. Innov. Manage. 8(4), 240-251. https://doi.org/10.1016/0737-6782(91)90046-2.

Krejcie, R.V., Daryle, M.W., 1970. Determining sample size for research activities. Educ. Psychol. Meas. 30(3), 607-610. https://doi.org/10.1177/001316447003000308.

Krystallis, A., Chryssohoidis, G., 2005. Consumers'willingness to pay for organic food: Factors 
that affect it and variation per organic product type. Br. Food J. 107(5), 320-343. https://doi.org/10.1108/00070700510596901.

Kuncoro, W., Suriani, W.O., 2018. Achieving sustainable competitive advantage through product innovation and market driving. Asia Pac. Manag. Rev. 23(3), 186-192. https://doi.org/10.1016/j.apmrv.2017.07.006.

Kurisu, K., 2015. How to survey PEBs, in: Pro-environmental behaviors. Springer, Tokyo, New York, pp. 67- 68.

Lassar, W.M., Manolis, C., Lassar, S.S., 2005. The relationship between consumer innovativeness, personal characteristics, and online banking adoption. Int. J. Bank Mark. 23(2), 176-199. https://doi.org/10.1108/02652320510584403.

Le Gall-Ely, M., 2009. Definition, Measurement and Determinants of the Consumer's Willingness to Pay: A Critical Synthesis and Avenues for Further Research. Recherche et Applications en Marketing (English Edition) 24(2), 91-112. https://doi.org/10.1177/205157070902400205.

Lee, R., Lee, J.H., Garrett, T.C., 2017. Synergy effects of innovation on firm performance. J. Bus. Res. 99, 507-515. https://doi.org/10.1016/j.jbusres.2017.08.032.

Li, G.X., Li, G.F., Kambele, Z., 2012. Luxury fashion brand consumers in China: Perceived value, fashion lifestyle, and willingness to pay. J. Bus. Res. 65(10), 1516-1522. https://doi.org/10.1016/j.jbusres.2011.10.019.

Li, J., Su, C., 2007. How face influences consumption: a comparative study of American and 
Chinese consumers. Int. J. Mark. Res. 49, 237 - 257.

Lin, C.H., Sher, P.J., Shih, H.Y., 2005. Past progress and future directions in conceptualizing customer perceived value. Int. J. Serv. Ind. Manage. 16(4), 318-336. https://doi.org/10.1108/09564230510613988.

Lowe, B., Alpert, F., 2015. Forecasting consumer perception of innovativeness. Technovation, 45-46, 1-14. https:/doi.org/10.1016/j.technovation.2015.02.001.

Mangis, C., 2017. Lego Boost Creative Toolbox. https://www.pcmag.com/review/355315/legoboost-creative-toolbox (accessed 7th October 2019).

Mathwick, C., Malhotra, N., Rigdon, E., 2001. Experiential value: Conceptualization, measurement and application in the catalog and Internet shopping environment. J. Retail. 77(1), 39-56. https:/doi.org/10.1016/s0022-4359(00)00045-2.

McNally, R.C., Cavusgil, E., Calantone, R.J., 2010. Product Innovativeness Dimensions and Their Relationships with Product Advantage, Product Financial Performance, and Project Protocol. J. Prod. Innov. Manage. 27(7), 991-1006. https://doi.org/10.1111/j.15405885.2010.00766.x.

Meehan, J.M., 2011. Pricing and profitability management: a practical guide for business leaders. John Wiley \& Sons, Hoboken.

Meterko, M., Restuccia, J.D., Stolzmann, K., Mohr, D., Brennan, C., Glasgow, J., Kaboli, P., 2015. Response rates, nonresponse bias, and data quality: results from a national survey of senior healthcare leaders. Public Opin. Q. 79(1), 130-144. https://doi.org/10.1093/poq/nfu052. 
Midgley, D.F., Dowling, G.R., 1978. Innovativeness: The Concept and Its Measurement. J. Consum. Res. 4(4), 229-242. https://doi.org/10.1086/208701.

Midgley, D.F., Dowling, G.R., 1993. A Longitudinal Study of Product Form Innovation: The Interaction between Predispositions and Social Messages. J. Consum. Res. 19(4), 611-625. https://doi.org/10.1086/209326.

Monroe, K.B., 2002. Pricing: Making profitable decisions (3rd ed.). McGraw- Hill, New York. Muigai, R.G., Gitau, S.N., 2018. Effect of Innovation Strategies on Financial Performance of the Banking Industry in Kenya. Eur. J. Econ. Financ. Res. 3(1), pp. 168-186.

National Bureau of Statistics of China, 2015. National Census. http://data.stats.gov.cn/easyquery.htm? $\mathrm{cn}=\mathrm{C} 01 \& \mathrm{zb}=\mathrm{A} 03060 \mathrm{H} \& \mathrm{sj}=2018$ (accessed on 21 November 2019).

NPD Group, 2018. U.S. Toy Industry Grows its Sales by 7 Percent in the First Half of 2018, Reports the NPD Group. https://www.npd.com/wps/portal/npd/us/news/press releases/2018/us-toy-industry-grows-its-sales-by-7-percent-in-the-first-half-of-2018-reportsthe-npd-group/ (accessed 6 November 2018).

Petrick, J.F., 2002. Development of a Multi-Dimensional Scale for Measuring the Perceived Value of a Service. J. Leis. Res. 34(2), 119-134. https://doi.org/10.1080/00222216.2002.11949965.

Preacher, K.J., Hayes, A.F., 2008. Asymptotic and resampling strategies for assessing and comparing indirect effects in multiple mediator models. Behav. Res. Methods, 40 (3), 879 - 
891. https://doi.org/10.3758/brm.40.3.879

Roehrich, G., 2004. Consumer innovativeness: concepts and measurements. J. Bus. Res. 57(6), 671-677. https://doi.org/10.1016/s0148-2963(02)00311-9.

Rogers, E.M., 1995. Diffusion of Innovations, Free Press, New York.

Rubera, G., Kirca, A.H., 2012. Firm Innovativeness and Its Performance Outcomes: A Meta Analytic Review and Theoretical Integration. J. Mark. 76(3), 130-147. https://doi.org/10.1509/jm.10.0494.

Sánchez-Fernández, R., Iniesta-Bonilla, M.Á., 2007. The concept of perceived value: A systematic review of the research. Mark. Theory 7(4), 427-451. https://doi.org/10.1177/1470593107083165.

Schindler, R., 2012. Pricing strategies: a marketing approach. Sage Publications Inc, Thousand Oaks, Calif.

Shavelson, R.J., Hubner, J.J., Stanton, G.C., 1976. Self-concept: Validation of construct interpretations. Rev. Educ. Res. 46, 407-441. https://doi.org/10.3102/00346543046003407.

Sheth, J.N., Newman, B.I., Gross, B.L., 1991. Why we buy what we buy: A theory of consumption values. J. Bus. Res. 22(2), 159-170. https://doi.org/10.1016/01482963(91)90050-8.

Shin, Y.H., Moon, H., Jung, S.E., Severt, K., 2017. The effect of environmental values and attitudes on consumer willingness to pay more for organic menus: A value-attitude-behavior approach. J. Hosp. Tour. Manag. 33, 113-121. https:/doi.org/10.1016/j.jhtm.2017.10.010. 
Sirgy, M.J., 1985. Self-image/product-image congruity and consumer decision-making. Int. J. Manage. 2(4), 49-63.

Smith, T.J., 2012. Pricing strategy: setting price levels, managing price discounts, \& establishing price structures. South-Western Cengage Learning, Mason, O. H.

Sweeney, J.C., Soutar, G.N., 2001. Consumer perceived value: The development of a multiple item scale. J. Retail. 77(2), 203-220. https://doi.org/10.1016/s0022-4359(01)00041-0.

Tran, A., 2018. LEGO Wins Three Awards at 2018 Toy of the Year Awards Gala. https:/www.thebrickfan.com/lego-wins-three-awards-at-2018-toy-of-the-year-awards-gala/ (accessed $7^{\text {th }}$ October 2019).

Truong, Y., 2013. A cross-country study of consumer innovativeness and technological service $\begin{array}{lllll}\text { innovation. } & \text { J. Retail. }\end{array}$ https://doi. org/10.1016/j.jretconser.2012.10.014.

Tsang, N.K.F., 2011. Dimensions of Chinese culture values in relation to service provision in hospitality and tourism industry. Int. J. Hosp. Manag. 30(3), 670-679. https://doi.org/10.1016/j.ijhm.2010.12.002.

Venkatesh, V., Davis, F.D., 2000. A theoretical extension of the technology acceptance model: Four longitudinal field studies. Manage. Sci. 46(2), 186-204. https://doi.org/10.1287/mnsc.46.2.186.11926.

Venkatesh, V., Morris, M., Davis, G., Davis, F., 2003. User acceptance of information technology: toward a unified view. MIS Q. 27(3), 425-478. https://doi.org/10.2307/30036540. 
Vtech, 2014. Zoo Explorers PlaysetTM User's Manual. https://www.vtechkids.com/assets/data/products/\%7B5E19251D-2218-4E83-A1CD

C361148C52DB\%7D/manuals/157200GGSAZooExplorersPlayset5.21.14.pdf $\quad$ (accessed $7^{\text {th }}$ October 2019).

Wang, T., Venkatesh, R., Chatterjee, R., 2007. Reservation Price as a Range: An IncentiveCompatible Measurement Approach. J. Mark. Res. 44(2), 200-213. https://doi.org/10.1509/jmkr.44.2.200.

Wei, S., Ang, T., Jancenelle, V.E., 2018. Willingness to pay more for green products: The interplay of consumer characteristics and customer participation. J. Retail. Consum. Serv. 45, 230-238. https://doi.org/10.1016/j.jretconser.2018.08.015.

William, M.D., 2014. Industrie 4.0 - Smart Manufacturing for The Future. Germany Trade \& Invest, Berlin.

Xie, B.C., Zhao, W., 2018. Willingness to pay for green electricity in Tianjin, China: Based on the contingent valuation method. Energy Policy 114, 98-107. https://doi. org/10.1016/j.enpol.2017.11.067.

Yalcinkaya, G., Calantone, R., Griffith, D., 2007. An Examination of Exploration and Exploitation Capabilities: Implications for Product Innovation and Market Performance. J. Int. Market. 15(4), 63-93. https://doi.org/10.1509/jimk.15.4.63.

Yang, J., Lu, Z., Wu, J. 2018. Smart-toy-edge-computing-oriented data exchange based on blockchain. J. Syst Architect, 87, 36-48. https://doi.org/10.1016/j.sysarc.2018.05.001 
Zeithaml, V.A., 1988. Consumer perceptions of price, quality, and value: a means-end model and synthesis of evidence. J. Mark. 52(3), 2. https://doi.org/10.2307/1251446.

Zhang, B., Fu, Z., Huang, J., Wang, J., Xu, S., Zhang, L., 2018. Consumers' perceptions, purchase intention, and willingness to pay a premium price for safe vegetables: A case study of Beijing, China. J. Clean Prod. 197, 1498-1507. https://oi.org/10.1016/j.jclepro.2018.06.273.

Appendices:

Appendix A : Questionnaire

\begin{tabular}{lll}
\hline Construct & Items & Source \\
\hline Perceived Product innovativeness & Fu and Elliott, \\
PI1 & Dash robot is innovative. & 2013 \\
PI2 & Dash robot is totally new to the market. \\
PI3 & Dash robot represents a new product category for \\
& consumers.
\end{tabular}

Perceived value

Sweeny and

Functional value for performance (quality) Soutar, 2001

QAL1 Dash robot has an acceptable standard of quality.

QAL2 Dash robot would last a long time.

QAL3 Dash robot has consistent quality.

QAL4 Dash robot would perform consistently.

Emotional value

EMO1 Dash robot is the one that I would enjoy.

EMO2 Dash robot is the one that I would feel relaxed about using.

EMO3 Dash robot would give me pleasure. 
EMO4 If I give Dash robot to my friends as a gift, Dash robot would give my friends pleasure.

Functional for money (price)

PRI1 Dash robot is reasonably priced.

PRI2 Dash robot offers value for money.

PRI3 Dash robot would be economical.

Social value

SCI1 Dash robot would help me to feel acceptable.

SCI2 Dash robot would improve the way I am perceived.

SCI3 Dash robot would make a good impression on other people.

SCI4 Dash robot would give its owner social approval.

Consumer innovativeness

Agarwal and

CI1 I know about new information technologies before Prasad,1998; most other people in my circle do. Citrin et al.,

CI2 Compared to my friends, I seek out relatively large 2000

information about the new information technologies.

CI3 If I heard about a new information

technology, I would look for ways to

experiment with it.

CI4 In general. I am hesitant to try out new

information technologies without considering the price.

Willingness to pay

Kealy and

WTP How much are you willing to pay for the Dash Turner, 1993 robot? 
Appendix B: Demographic variables

\begin{tabular}{|c|c|c|}
\hline Characteristic & Frequency & $\%$ \\
\hline \multicolumn{3}{|l|}{ Gender } \\
\hline Male & 201 & 50.4 \\
\hline Female & 198 & 49.6 \\
\hline \multicolumn{3}{|l|}{ Age } \\
\hline 22 and below & 22 & 5.5 \\
\hline $23 \sim 28$ & 136 & 34.1 \\
\hline 29 34 & 122 & 30.6 \\
\hline $35 \sim 40$ & 89 & 22.3 \\
\hline $41 \sim 46$ & 19 & 4.8 \\
\hline $47 \sim 52$ & 4 & 1 \\
\hline $53 \sim 59$ & 5 & 1.3 \\
\hline 60 and above & 2 & 0.5 \\
\hline \multicolumn{3}{|l|}{ Education } \\
\hline $\begin{array}{l}\text { No higher } \\
\text { experience }\end{array}$ & 20 & 5.0 \\
\hline Associate & 36 & 9.0 \\
\hline Bachelor & 215 & 53.9 \\
\hline Master & 110 & 27.6 \\
\hline $\mathrm{PhD}$ & 18 & 4.5 \\
\hline \multicolumn{3}{|c|}{ Income per month (RMB) } \\
\hline 1000 and below & 18 & 4.5 \\
\hline $1001 \sim 2000$ & 21 & 5.3 \\
\hline $2001 \sim 3000$ & 32 & 8.0 \\
\hline $3001 \sim 4000$ & 37 & 9.3 \\
\hline $4001 \sim 5000$ & 24 & 6.0 \\
\hline $5001 \sim 6000$ & 22 & 5.5 \\
\hline
\end{tabular}




\begin{tabular}{lll}
$6001 \sim 7000$ & 35 & 8.8 \\
$7001 \sim 8000$ & 25 & 6.3 \\
$8001 \sim 9000$ & 15 & 3.8 \\
$9001 \sim 10000$ & 6 & 1.5 \\
$10001 \sim 11000$ & 13 & 3.3 \\
$11001 \sim 12000$ & 16 & 4.0 \\
$12001 \sim 13000$ & 17 & 4.3 \\
$13001 \sim 14000$ & 0 & 0 \\
14000 and above & 118 & 29.6 \\
\hline
\end{tabular}

\section{Authors' biographies}

Miss. Fangyu Zhang joined Business School at The University of Auckland as a fulltime Master of Commerce in Global Management and Innovation student after completing a research master's degree in Xi'an Jiaotong-Liverpool University in 2019 and a bachelor's degree in Accounting from the School of Business at The University of Liverpool in 2017.

Mr. Siwei Sun joined Business School at The University of Auckland as a full-time Master of Commerce in Global Management and Innovation student after completing a research master's degree in Xi'an Jiaotong-Liverpool University in 2019, a master's degree in International Business from the School of Business at The University of Nottingham, Ningbo, China in 2015. He has published a few research papers.

Dr. Chenlin Liu is a postdoctoral researcher at the School of Economics and Management at Tsinghua University after completing a Doctorate of Philosophy in Management at Macau University of Science and Technology in 2018. 
Prof. Victor Chang is a Professor at the School of Computing, Engineering and Digital Technologies at Teesside University. He is widely regarded as an expert on IoT, Data Science, Cloud/Fog Computing, AI, security and information management. He won IEEE Outstanding Service Award in 2015, best papers in 2012, 2015 and 2018, the 2016 European award: Best Project in Research, 2016 SEID Excellent Scholar, Suzhou, China, Outstanding Young Scientist award in 2017, 2017 special award on Data Science, 2017, 2018 and 2019 INSTICC Service Awards and numerous awards since 2012. He is a visiting scholar/Ph.D. examiner at several universities, an Editor-in-Chief of IJOCI \& OJBD journals, Editor of FGCS and Associate Editor of TII. He is one of the most highly cited researchers at his university, with more than 6,500 citations up-to-date. He has given 18 conference keynotes internationally and is also one of the most influential and active young scientists. He founded several workshops and conferences, particularly IoTBDS http:/www.iotbd.org and COMPLEXIS http://www.complexis.org since the Year 2015, and FEMIB femib.scitevents.org since the Year 2018 to establish and foster global research communities. 